\title{
PENGGUNAAN TEKNIK PELATIHAN DASAR DI ALAM TERBUKA UNTUK MENINGKATKAN KETERAMPILAN MEMBACA PUISI SISWA KELAS XII IPS 1 SMA NEGERI 16 PEKANBARU
}

\author{
Haswinta Riora \\ SMA Negeri 16 Pekanbaru, Indonesia \\ haswintariora1@gmail.com
}

\begin{abstract}
Reading poetry is one of the skills in the field of literature included in the learning of Indonesian language and literature in high school. Reading poetry is not the same as reading in general. Reading poetry requires a special skill, namely a reading expression skill. Reading expression trains students to be creative in expressing a poetic text and creating appreciation, vocal techniques, and appearance that are following the contents of the poetry. Unfortunately, based on the field observation, it found that the poetry reading skills of students in class XII Social Science 1 at SMAN 16 Pekanbaru were still low, as seen from the lack of students' ability in ensouling, vocal techniques, and performances that did not match the contents of the poetry they read. The problem formulation of this study was whether the use of basic outdoor training techniques can improve students' poetry reading skills and how the changes of students' behaviors in reading poetry learning after applying basic outdoor training techniques in class XII Social Science 1 at SMAN 16 Pekanbaru? This study aimed to describe the improvement of students' ability in reading poetry and to investigate the changes of students' behaviors in reading poetry learning after applying basic outdoor training techniques in class XII Social Science 1 at SMAN 16 Pekanbaru. The type of this research was classroom action research. The results of this study show that there was an improvement of students' poetry reading skills with an average score of the cycle I was 69.32 and an average score of the cycle II was 82.97. In other words, there is an increase from cycle I to cycle II of 13.65 points or $19.69 \%$. While the changes in students' behavior in reading poetry learning experience the addition of positive behavior.
\end{abstract}

Keywords: outdoor training, reading poetry, skill.

\begin{abstract}
ABSTRAK
Membaca puisi merupakan salah satu keterampilan dalam bidang sastra yang termasuk kedalam pembelajaran bahasa dan sastra Indonesia di sekolah Menengah atas. Membaca puisi tidak sama dengan membaca pada umumnya. Membaca puisi memerlukan keterampilan khusus, yaitu keterampilan membaca ekspresi. Sayangnya, berdasarkan peninjauan lapangan ditemukan bahwa keterampilan membaca puisi siswa di Kelas XII IPS 1 SMA Negeri 16 Pekanbaru ternyata masih rendah, terlihat dari kurangnya kemampuan siswa dalam menciptakan penghayatan, teknik vokal, dan penampilan yang tidak sesuai dengan isi puisi yang dibacanya. Masalah dalam penelitian ini adalah Apakah penggunaan teknik pelatihan dasar di alam terbuka mampu meningkatkan keterampilan membaca puisi siswa dan bagaimana perubahan tingkah laku siswa dalam mengikuti pembelajaran membaca puisi setelah diterapkan teknik pelatihan dasar di alam terbuka di kelas XII IPS 1 SMA Negeri 16 Pekanbaru? Tujuan penelitian ini adalah mendeskripsikan peningkatan kemampuan siswa membaca puisi setelah diterapkan teknik pelatihan dasar di alam terbuka dan mendeskripsikan perubahan perilaku siswa dalam mengikuti pembelajaran membaca puisi melalui teknik pelatihan dasar di alam terbuka pada siswa kelas XII IPS 1 SMA Negeri 16 Pekanbaru. Jenis penelitian ini adalah PTK (penelitian tindakan kelas). Hasil penelitian ini adalah terdapat peningkatan keterampilan membaca puisi siswa dengan rata-rata nilai hasil tes siklus I sebesar 69,32 dan pada siklus II diperoleh nilai rata-rata sebesar 82,97. Hal ini menunjukkan peningkatan

Penggunaan Teknik Pelatihan Dasar di Alam Terbuka untuk Meningkatkan Keterampilan Membaca Puisi Siswa Kelas XII IPS 1 SMA Negeri 16 Pekanbaru
\end{abstract}


dari siklus I ke siklus II sebesar 13,65 poin atau 19,69\% sedangkan perubahan perilaku siswa dalam mengikuti pembelajaran membaca puisi mengalami penambahan perilaku positif.

\section{Kata Kunci: keterampilan membaca puisi, teknik pelatihan dasar di alam terbuka}

\section{PENDAHULUAN}

Keterampilan bersastra dan berbahasa merupakan keterampilan yang tercakup dalam pembelajaran Bahasa dan sastra di sekolahsekolah Indonesia. Pembelajaran Bahasa dan Sastra ini bertujuan untuk mengembangkan siswa baik dalam keterampilan berbahasa maupun bersastra. Melalui pembelajaran sastra siswa dapat mengungkapkan ide kreatifnya. Adanya pengalaman-pengalaman dalam pembelajaran sastra akan memperkaya nuansa batin dan pola pikir siswa yang akhirnya dapat memengaruhi tanggapan siswa terhadap dirinya, alam sekitar, dan penciptanya.

Membaca puisi yang baik memerlukan beberapa keterampilan dalam bersastra termasuk kemampuan untuk mengekspresikan dirinya melalui karya sastra. Pengembangan keterampilan bersastra seperti bermain peran, membacakan cerpen, menyimak cerpen, membaca syair bahkan membaca puisi pun perlu diupayakan agar keterampilan bersastra siswa menjadi lebih baik.

Salah satu pembelajaran karya sastra adalah pembelajaran membaca puisi. Karya sastra berbentuk puisi bersifat konsentrif dan intensif (Suharianto, 2005:34). Bersifat konsentrif maksudnya pemusatan penggunaan bahasa yang mana si pengarang tidak menjelaskan secara terperinci apa yang diungkapkannya. Akan tetapi mengungkapkannya dalam bentuk gaya bahasa atau majas sedangkan bersifat intensif maksudnya pemadatan kalimat yang hanya terdiri dari kosa kata yang penting atau yang pokok saja oleh si pengarang yang mewakili ungkapan perasaan atau pendapatnya. Oleh karena itu, pemahaman makna puisi dilakukan dengan mengembalikan konsep dari kosa kata yang hilang dari apa yang disampaikan oleh pengarangnya.

Menurut Suharianto (2005:34-35) dalam sebuah puisi, konsentrasi dan intensifikasi yang dilakukan pengarang tidak hanya menekankan pada apa yang disampaikan, tetapi juga bagaimana cara menyampaikannya. Pada bagian inilah siswa diminta untuk merasakan dan mencoba mengungkapkan apa makna isi dari puisi yang disampaikan pengarang melalui pembacaan bait-bait puisi sesuai apa yang ditulis oleh pengarang.

Pada hakikatnya puisi adalah ungkapan perasaan atau pikiran penulisnya. Puisi juga bisa tercipta berdasarkan pandangan hidup si penulis yang kemudian direfleksikan kedalam karyanya atau kreasi seni menggunakan bahasa sebagai medianya (Nuryatin, 2005:103-104; Fatoni dan Nuryatin, 2016:58; Sulkifli dan Marwati, 2016; dan Kamus Istilah Sastra dalam Zulfadli, 2017:2). Kalimat yang ditulis oleh penyair mengandung makna tertentu yang merupakan buah dari hasil pemikiran berupa pendapat, ide, gagasan serta pengetahuannya terhadap apa yang dirasakan oleh si pengarang sebagai respons dari apa yang ada maupun apa yang terjadi disekelilingnya. Kalimat puisi biasanya terangkai dari kata-kata yang bersifat lirik, namun terdapat juga puisi yang berupa cerita.

Eksistensi puisi pada hakikatnya merupakan bentuk upaya "mengabadikan" pengalaman yang dirasakan oleh si penulis dengan sudut pandang bahwa sesuatu tersebut dirasakan mengesankan atau mengandung nilai dan arti mendalam. Puisi menggambarkan keadaan dimana terdapat pesan yang khusus yang disampaikan pengarang melalui kalimat dengan gaya bahasa tersendiri bisa berupa makna yang sebenarnya maupun kiasan (Waluyo, 2005:1). Para pembaca perlu mempelajari pesan dan memahami makna sebenarnya dari apa yang dikarang oleh penulisnya.

Membaca merupakan aktivitas untuk memahami bahasa tulis yang disampaikan oleh penulis. Membaca pada hakikatnya adalah pemecahan kode dan penerimaan pesan. Pesan yang disampaikan berupa kode huruf-huruf yang membentuk kata, lalu kata-kata tersebut 
tersusun dan membentuk kalimat yang mengandung makna berupa informasi dari si penulis kepada si pembaca. Dalam hal ini, si penulis berperan sebagai sender (penyampai pesan) dan si pembaca berperan sebagai receiver (penerima pesan). Penyampai pesan membuat kode yang mengandung pesan atau informasi berupa pengetahuan, sedangkan penerima pesan berusaha memecahkan kode yang diterima berupa pesan atau informasi yang secara aktif sehingga maknanya dapat dipahami dan menambah pengetahuan (Santoso, 2012:63).

Senada dengan pendapat Santoso Tarigan dalam Asnawi (2017:54) mengatakan Membaca merupakan satu aktivitas mencari informasi dari sumber tertulis. Aktivitas membaca memberikan peran yang begitu penting dalam kehidupan seseorang. Membaca adalah suatu proses yang dilakukan serta dipergunakan oleh pembaca untuk memperoleh pesan yang hendak disampaikan penulis melalui media kata-kata atau bahasa tulis. Dengan demikian betapa pentingnya membaca untuk siswa sebagai dasar untuk menimba ilmu di sekolah.

Pada dasarnya membaca dibedakan menjadi dua yaitu membaca bahasa dan membaca sastra (Tarigan, 2008:37). Salah satu jenis membaca sastra adalah membaca puisi secara lisan untuk orang lain. Membaca puisi merupakan membaca indah, yaitu membaca dengan memerhatikan intonasi, rima, dan irama serta jeda yang tepat, sehingga bunyibunyi yang dihasilkan terasa enak didengar oleh telinga.

Dalam konsep kajian membaca bahasa, membaca puisi berarti upaya untuk memahami serta menghayati isi kandungan makna dan segala sesuatu yang terdapat dalam puisi (Gani, 2014:38). Dalam kegiatan ini dimaksudkan bahwa apa yang dirasakan atau apa yang difikirkan oleh si penulis puisi dirasakan dan difikirkan pula oleh si pembaca puisi. Dengan kata lain, kegiatan membaca puisi tidak hanya sekedar melisankan atau menyuarakan puisi, akan tetapi juga melibatkan ekspresi jiwa dan perasaan dari makna yang tertuang dalam puisi tersebut (Doyin, 2008:2).
Aktivitas membaca puisi memerlukan penghayatan, teknik vokal dan penampilan yang selaras dengan kandungan isi puisi ketika dibaca di depan pendengar. Kegiatan ini ditujuan agar si pendengar atau penonton turut merasakan dan memahami isi dari teks puisi. Penyampaian pembacaan puisi yang baik akan mampu membuat para pendengar larut dalam keadaan dimana mereka mampu merasakan keadaan dari apa yang diilustrasikan dalam puisi.

Dalam membaca puisi juga diperlukan keterampilan khusus, yaitu keterampilan membaca ekspresi, sehingga si pembaca perlu memiliki keterampilan ini untuk meluapkan emosi yang tepat dalam berekspresi. Melalui keterampilan membaca ekspresi, siswa dilatih untuk berkreasi dalam mengekspresikan isi teks puisi dan sekaligus menciptakan penghayatan, teknik vokal dan penampilan yang tepat sesuai dengan kaidah keindahan dalam membaca sastra. Dengan mempertimbangkan bahwa keterampilan membaca puisi tidaklah sama dengan keterampilan membaca biasa, maka siswa perlu memahami tentang cara membaca puisi yang baik ditinjau dari aspek membaca sastra.

Melalui pembelajaran membaca puisi dalam mata pelajaran Bahasa Indonesia, siswa dilatih untuk mengembangkan keterampilan seni membaca indah dan keterampilan untuk mengekspresikan diri dengan percaya diri serta memberi kebebasan untuk mengungkapkannya sesuai dengan penjiwann siswa. Disini keterampilan siswa membaca puisi perlu diasah dalam kegiatan belajar di sekolah serta melalui latihan-latihan yang teratur. Keadaan lingkungan yang kondusif juga turut membantu meningkatkan keefektifan dalam kegiatan pembelajaran agar tujuan pembelajaran membaca puisi dapat dicapai. Adapun tujuan pembelajaran membaca puisi di sekolah adalah untuk membudayakan pembacaan puisi serta menciptakan pembelajaran yang menarik dan menyenangkan. Keadaan yang nyaman dan kondusif dapat membuat siswa melakukan aktivitas pembelajaran secara fokus dan leluasa mengembangkan dirinya untuk meningkatkan keterampilan-keterampilan yang 
dipelajari termasuk keterampilan membaca puisi. Lingkungan yang kondusif juga menjadi salah satu faktor untuk menciptakan suasana yang harmonis antara guru dan siswa. Suasana yang harmonis juga tercipta karena adanya hubungan komunikasi yang baik antara guru dan siswa dan juga sesama siswa. Dengan demikian, dalam pembelajaran membaca puisi tidak hanya ditekankan pada materi pembelajaran itu sendiri, melainkan juga pada aspek lingkungan keadaan dimana proses pembelajaran itu dilaksanakan.

Membaca puisi merupakan hal yang penting, tetapi berdasarkan hasil observasi di kelas XII IPS 1 SMA Negeri 16 Pekanbaru ternyata tingkat keterampilan siswa dalam membaca puisi masih rendah. Penyebab rendahnya keterampilan membaca puisi siswa dikarenakan guru mata pelajaran kurang menekankan pada materi tentang teknik-teknik membaca puisi, penjelasan yang hanya sekilas saja, kurangnya pendalaman materi tentang penguasaan keterampilan membaca puisi serta media dan strategi yang kurang tepat pada saat mengajar pada pembelajaran membaca puisi. Ditemukan juga kenyataan bahwa sebagian besar siswa merasa jenuh ketika belajar karena metode pengajaran yang paling sering digunakan oleh guru adalah metode ceramah, sehingga upaya guru dalam meningkatkan keterampilan siswa dalam seni membaca puisi masih belum memenuhi harapan. Di dalam kelas guru hanya menjelaskan pengertian puisi dan syarat dalam pembacaan puisi tanpa menerangkan secara mendetail tentang penguasaan teknik vokal, penghayatan terhadap isi puisi dan penampilan yang harus dikuasai ketika membaca puisi. Melaui pembelajaran dengan cara tersebut, tampaklah hasil yang kurang memuaskan, kemampuan siswa dalam membaca puisi dapat dikatakan masih di bawah harapan. Pada umumnya, siswa belum menguasai teknik vokal, penghayatan dan keterampilan yang baik dalam membaca puisi. Oleh karena itu, perlu diadakan upaya dan perhatian yang serius untuk membantu siswa mengembangkan keterampilan membaca puisi mereka.

Dengan mempertimbangkan kekurangan-kekurangan yang ada dilapangan mengenai keterampilan membaca puisi pada siswa kelas XII IPS 1 SMA Negeri 16 Pekanbaru, maka hal tersebut menjadi sebuah titik tolak untuk melakukan penelitian ini. Adapun tujuan dari penelitian ini adalah untuk meningkatkan keterampilan membaca puisi siswa berdasarkan indikator penghayatan, vokal dan penampilan (performance) yang tepat dalam membaca puisi pada siswa kelas XII IPS 1 SMA Negeri 16 Pekanbaru melalui penerapan pengajaran yang menekankan pada pemahaman dan peningkatan keterampilan membaca puisi dengan menggunakan teknik pelatihan dasar di alam terbuka.

Teknik pelatihan dasar di alam terbuka adalah teknik pembelajaran yang dilakukan diluar kelas dengan tujuan untuk memberikan kenyamanan belajar bagi siswa untuk mengekspresikan dirinya di alam terbuka. Pembelajaran bisa dilakukan di taman sekolah, taman kota atau objek wisata alam namun tetap fokus terhadap hasil pembelajaran. Teknik ini diharapkan mampun meningkatkan keterampilan membaca puisi karena alam pada dasarnya menciptakan suasana yang natural sehingga baik secara lansung maupun tidak lansung siswa mendapatkan manfaat kenyamanan dan ketentraman dari alam untuk mengembangkan kemampuan dirinya. Pelatihan dasar di alam terbuka ini dikombinasikan dengan pelatihan peningkatan keterampilan membaca puisi seperti pelatihan pernafasan, pelatihan konsentrasi, pelatihan vokal, pelatihan olah tubuh, dan pelatihan ekspresi. Selain itu, pelatihan dasar ini diyakini dapat meningkatkan kepercayaan diri siswa, karena siswa tidak terpaku belajar di dalam ruangan yang terbatas tetapi merasa lebih leluasa mengekspresikan dirinya dengan berada di suasana pemandangan yang luas di alam terbuka sehingga kepercayaan diri pun muncul. Oleh karena itu, pelatihan ini perlu dilaksanakan beberapa kali sebelum pengambilan nilai atau pengukuran kemampuan membaca puisi. Semakin sering diadakannya teknik pelatihan dasar di alam terbuka ini, maka semakin baik pula tingkat keterampilan membaca puisi siswa. Terlebih lagi, dengan adanya pembelajaran di alam terbuka, maka siswa akan lebih termotivasi 
dalam mengikuti pembelajaran karena suasana di alam terbuka membuat siswa lebih leluasa dalam berlatih.

Puisi merupakan bagian dari pelajaran sastra yang akan mendapatkan perhatian siswa. Bahkan ada kemungkinan siswa akan gemar membaca puisi setelah berlatih, melihat, dan mempraktikkan langsung dengan baik melalui teknik pelatihan dasar. Teknik ini sangat memudahkan siswa dalam memahami tentang cara membaca puisi yang lebih baik sesuai dengan kaidah membaca puisi indah. Melalui pembelajaran dengan teknik pelatihan dasar di alam terbuka ini diharapkan siswa akan menjadi lebih senang dan santai saat mengikuti proses belajar tentang materi membaca puisi. Selain itu, dengan adanya teknik pelatihan dasar dialam terbuka ini maka diharapkan dapat menjadikan siswa lebih bebas dalam berekspresi.

Adapun rumusan masalah yang menjadi landasan dalam penelitian ini adalah:

1. Apakah penggunaan teknik pelatihan dasardi alam terbuka mampu meningkatkan keterampilah membaca puisi siswa di Kelas XII IPS 1 SMA Negeri 16 Pekanbaru?

2. Bagaimana perubahan tingkah laku siswadalam mengikuti pembelajaran membaca puisi setelah diterapkan teknik pelatihan dasar di alam terbuka pada siswa Kelas XII IPS 1 SMA Negeri 16 Pekanbaru?

berikut:

Tujuan penelitian ini adalah sebagai

1. Mendeskripsikan peningkatan kemampuan siswa membaca puisi setelah diterapkan teknik pelatihan dasar di alam terbuka pada siswa Kelas XII IPS 1 SMA Negeri 16 Pekanbaru.

2. Mendeskripsikan perubahan perilaku siswa dalam mengikuti pembelajaran membaca puisi melalui teknik pelatihan dasar di alam terbuka pada siswa Kelas XII IPS 1 SMA Negeri 16 Pekanbaru.

Hipotesis tindakan dalam penelitian ini yaitu terdapat peningkatan keterampilan membaca puisi dan perubahan perilaku siswa setelah dilakukan pembelajaran membaca puisi melalui teknik pelatihan dasar di alam terbuka pada siswa kelas XII IPS 1 SMA Negeri 16 Pekanbaru.

\section{METODOLOGI PENELITIAN}

Penelitian ini merupakan penelitian tindakan kelas (PTK). Menurut Arikunto (2010:102) penelitan tindakan kelas adalah penelitian yang menawarkan cara atau prosedur baru untuk memperbaiki dan meningkatkan kinerja dan kualitas pendidikan. Dengan kata lain, penelitian ini merupakan penelitian yang bersifat reflektif. Dalam penelitian ini, peningkatan atau perbaikan kualitas pembelajaran dilaksanakan melalui serangkaian tahapan.

Penelitian ini terdiri dari empat tahapan yang merupakan bentuk proses pengkajian berulang pada tiap tahapannnya. Adapun keempat tahapannya adalah tahapan perencanaan, tahapan tindakan, tahapan pengamatan dan tahapan refleksi. Terdapat dua siklus dalam penelitian ini, yakni siklus I dan siklus II. Siklus I merupakan tindakan awal penelitian yang bertujuan untuk mengetahui seberapa baik keterampilan siswa dalam membaca puisi. Hasil yang diperoleh dari siklus I kemudian digunakan sebagai refleksi untuk melakukan tindakan selanjutnya pada siklus II. Adapun tindakan dalam siklus II meliputi analisis dan penilaian untuk mengkaji kemungkinan adanya permasalahan baru yang muncul, maka jika hal ini terjadi perlu adanya tahapan perencanaan ulang, tindakan ulang, pengamatan ulang dan refleksi ulang.

Penelitian ini menerapkan model penelitian tindakan kelas yang kemukakan oleh Kemmis dan Taggart. Model ini menekankan pada tahapan yang dilakukan secara berulang-ulang hingga tercapainya tujuan yang diharapkan dalam sebuah penelitian. Desain penelitian tindakan kelas model Kemmis dan Taggart dapat di liahat pada gambar 1 . 


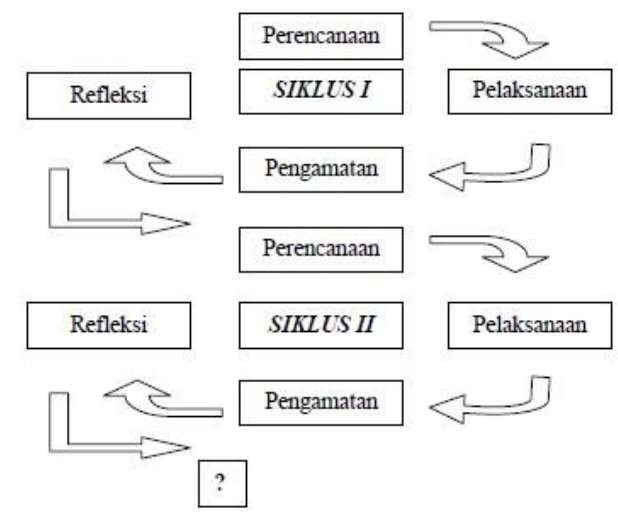

Gambar 1. Desain Penelitian Tindakan Kelas Model Kemmis dan Taggart (Arikunto, 2010:137).

Pada model penelitian tindakan kelas yang telah dikembangkan oleh Kemmis dan Taggart ini, tindakannya terdiri dari empat tahapan mulai dari perencanaan, pelaksanaan, observasi, dan refleksi (Arikunto, (2010:138140). Alur siklusnya saling berkelanjutan dan berkesinambungan. Pada siklus pertama, fokus penelitian adalah tindakan terhadap masalah yang diamati, namun jika hasilnya masih kurang maka dilanjutkan ke siklus berikutnya yang merupakan perbaikan dari siklus pertama. Apabila hasil penelitian telah menunjukkan peningkatan atau tujuan penelitian yang diharapkan telah tercapai, maka siklus dalam penelitian tindakan kelas ini sudah dapat dihentikan.

Penelitian ini dilakukan di SMA Negeri 16 Pekanbaru yang beralamat di Jl. Pramuka, Lembah Sari, Kec. Rumbai Pesisir. Pelaksanaan kegiatan dilaksanakan mulai tanggal 18 Juli 2019 sampai dengan 15 Agustus 2019.

Subjek penelitian ini adalah siswa kelas XII IPS 1 SMA Negeri 16 Pekanbaru yang mengikuti pembelajaran bahasa Indonesia yang berjumlah sebanyak 34 orang. Kemudian, objek dalam penelitian ini adalah keterampilan membaca puisi siswa kelas XII IPS 1 SMA Negeri 16 Pekanbaru dengan menggunakan teknik pelatihan dasar di alam terbuka.

Adapun populasi dalam penelitian ini terdiri dari 111 siswa yang merupakan siswa kelas XII di SMA Negeri 16 Pekanbaru. Sedangkan yang dijadikan sampel dalam penelitian ini adalah siswa kelas XII IPS 1 yang terdiri dari 34 siswa.

Terdapat tiga bagian siklus dalam prosedur pelaksanaan Penelitian Tindakan Kelas (PTK) ini, yakni pra siklus, siklus I, dan siklus II. Tiap siklus terdiri dari kesatuan tahapan mulai dari tahapan penyusunan rancangan sampai dengan tahapan refleksi. Dengan kata lain, secara lebih jelasnya dapat dinyatakan bahwa tiap-tiap siklus mencakup (1) perencanaan (2) tindakan, (3) observasi, dan (4) refleksi.

Dalam penelitian ini, teknik pengumpulan data yang digunakan adalah melalui observasi, wawancara, catatan harian lapangan, dokumentasi dan tes untuk mengukur keterampilan membaca puisi siswa pada saat pembelajaran berlansung baik pada pra siklus, siklus I dan siklus II.

Hasil data yang diperoleh dari tiap siklus akan dibandingkan berdasarkan hasil tes maupun non tes. Perbandingan hasil tes dimaksudkan untuk mengukur peningkatan keterampilan membaca puisi siswa setelah dilakukannya upaya melalui pembelajaran dengan teknik pelatihan dasar dialam terbuka, sedangkan perbandingan hasil non tes dimaksudkan untuk mengetahui apakah terdapat perubahan perilaku siswa dalam mengikuti pembelajaran membaca puisi setelah diterapkannya teknik pelatihan dasar dialam terbuka.

\section{HASIL DAN PEMBAHASAN}

\section{Gambaran Umum SMA 16 Pekanbaru}

SMA Negeri 16 Pekanbaru yang beralamat di Jl. Pramuka, Lembah Sari, Kec. Rumbai Pesisir kota Pekanbaru. Secara umum situasi sekolah cukup kondusif. SMA Negeri 16 Pekanbaru terletak jauh dari keramaian kota dan teletak di tepi kota Pekanbaru sehingga suasana di sekolah ini cukup kondusif dan sangat tenang untuk melaksanakan pembelajaran. Disekitar sekolah ini juga terdapat banyak pepohonan hijau karena sekolah ini berkonsep Go Green yang menciptakan suasana nyaman bagi siswa dan guru. 
Sarana dan prasarana yang dimiliki oleh SMA Negeri 16 Pekanbaru cukup lengkap, yang terdiri dari ruang kelas, ruang guru, ruang kepala sekolah, ruang TU, mushola, lapangan upacara, lapangan bola voli labor komputer, perpustakaan, UKS, aula, kantin, dan koperasi. Keadaan lingkungan dan ruang kelas cukup nyaman dan kondusif. Setiap ruang kelas terdapat sekitar 35 pasang meja dan kursi dalam kondisi yang baik dan layak guna. Didalam kelas terdapat papan tulis dan juga dilengkapi LCD proyektor.

\section{Deskripsi Data Penelitian}

Waktu pelaksanaan penelitian tindakan kelas ini dimulai sejak tanggal 18 Juli 2019 hinggal tanggal 15 Agustus 2019. Langkah-langkah dalam pelaksanaan penelitian ini mengikuti urutan prosedur penelitian yang telah ditetapkan sesuai skema proses penelitian mulai dari identifikasi masalah, menganalisis masalah, merumuskan gagasan pemecahan masalah, melaksanakan tindakan, dan tahap refleksi, serta rekomendasi tindakan berikutnya.

\section{Hasil Penelitian}

\subsection{Hasil Penelitian Tindakan Kelas Siklus I}

Siklus I dalam penelitian ini terdiri dari 2 (dua) pertemuan. Pertemuan pertama diadakanan pada hari Jumat tanggal 19 Juli 2019 dengan durasi waktu 2x45 menit. Pada pertemuan ini dibahas tentang materi pelajaran mengenai pengertian dan ciri-ciri teks puisi. Pada pertemuan ini, siswa mulai dikenalkan dengan teknik pelatihan dasar membaca puisi di alam terbuka.

Pertemuan kedua dalam siklus I ini diadakan pada hari Selasa tanggal 23 Juli 2019 dengan durasi waktu 2x45 menit. Pada pertemuan ini, siswa mulai mendalami materi pembacaan puisi dengan menggunakan teknik pelatihan dasar di alam terbuka. Siswa dilatih untuk menjiwai puisi dan meresapi lingkungan alam sekitar serta memadupadankan perasaan diri dengan suasana alam dalam mengekpresikan makna puisi saat membacanya.

Setelah pembelajaran pada siklus I selesai, kemudian peneliti melakukan evaluasi post-test 1 dengan memberikan tes membaca puisi serta menanyakan komponen pembacaan puisi kepada peserta didik dari apa yang mereka pahami selama proses pembelajaran siklus I. Setelah dilaksanakannya pembelajaran selama dua kali pertemuan dan satu kali pertemuan post-test 1 , jumlah peserta didik yang mencapai nilai KKM mengalami peningkatan dibandingkan nilai tes pada prasiklus.

Adapun siswa yang mencapai nilai KKM yakni sebesar 78 ada 11 siswa. Sementara itu, jika dilihat dari perolehan nilai siswa dalam membaca puisi menurut pengategorian skor, siswa yang memperoleh nilai kategori sangat baik atau baik berjumlah ada 30 siswa. Hal ini dapat dilihat pada tabel berikut.

Tabel 1. Distribusi nilai post-test 1 keterampilan membaca puisi dalam skala 100

\begin{tabular}{|l|l|c|c|c|}
\hline $\begin{array}{l}\text { No } \\
.\end{array}$ & $\begin{array}{l}\text { Katego } \\
\text { ri }\end{array}$ & $\begin{array}{l}\text { Rentan } \\
\text { g Skor }\end{array}$ & $\begin{array}{l}\text { Frekuen } \\
\text { si }\end{array}$ & $\begin{array}{l}\text { Persentas } \\
\text { e }\end{array}$ \\
\hline 1. & $\begin{array}{l}\text { Sangat } \\
\text { baik }\end{array}$ & $85-100$ & 1 & $2,94 \%$ \\
\hline 2. & Baik & $70-84$ & 18 & $52,94 \%$ \\
\hline 3. & Cukup & $55-69$ & 14 & $41,18 \%$ \\
\hline 4. & $\begin{array}{l}\text { Kurang } \\
\text { baik }\end{array}$ & $0-54$ & 1 & $2,94 \%$ \\
\hline \multicolumn{2}{|l}{ Jumlah } & & $\mathbf{3 4}$ & $\mathbf{1 0 0 \%}$ \\
\hline
\end{tabular}

Berdasarkan tabel diatas, diketahui bahwa pada post-test Siklus1, peserta didik yang mencapai nilai dengan kategori sangat baik dengan rentang skor 85-100 berjumlah 1 orang $(2,94 \%)$. Peserta didik yang mencapai nilai dengan kategori baik dengan rentang skor $70-84$ berjumlah 18 orang $(52,94 \%)$. Peserta didik yang mencapai nilai dengan kategori cukup dengan rentang skor 55-69 berjumlah 14 orang $(41,18 \%)$. Peserta didik yang mencapai nilai dengan kategori kurang baik dengan rentang skor $0-54$ berjumlah 1 orang $(2,94 \%)$. Nilai tersebut dihitung dengan pada skala maksimal 100.

Perbandingan rentang skor hasil tes membaca puisi peserta didik pada siklus I dapat dilihat pada gambar berikut ini. 


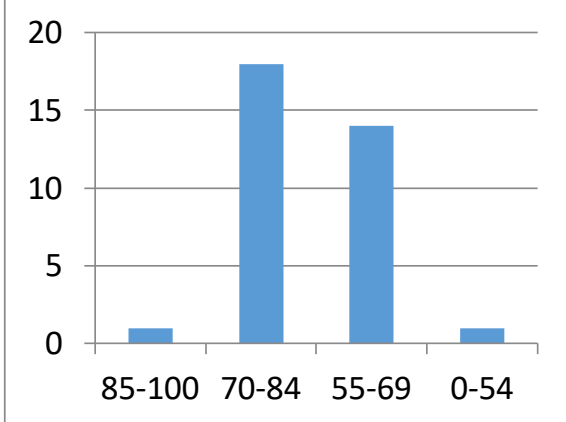

Grafik 1. Grafik persentase peningkatan jumlah peserta didik pada siklus I

Grafik di atas menunjukkan bahwa pada siklus I, jumlah peserta didik yang mencapai nilai KKM sebanyak 11 orang atau sebesar $32,35 \%$, tetapi sebanyak 23 peserta didik atau sebesar $67,65 \%$ masih mendapatkan nilai di bawah KKM.

\subsection{Hasil Penelitian Tindakan Kelas Siklus II}

Siklus II dalam penelitian ini juga terdiri dari 2 (dua) pertemuan. Pertemuan pertama diadakanan pada hari Jumat tanggal 2 Agustus 2019 dengan durasi waktu 2x45 menit. Pada pertemuan ini, materi pelajaran yang disampaikan oleh peneliti adalah teknik dasar membaca puisi, yang merupakan materi yang telah disampaikan pada pertemuan sebelumnya. Dalam pertemuan ini, siswa lebih dilatih untuk membaca puisi dengan penuh penghayatan dan juga dilatih untuk menggunakan teknik vokal yang baik saat mengucapkan kalimat yang terdapat pada teks puisi. Para siswa melakukan latihan untuk meningkatkan performance (penampilan) mereka dalam membaca puisi di alam terbuka.

Pertemuan kedua pada siklus II diadakan pada hari Selasa tanggal 06 Agustus 2019 dengan durasi waktu 2x45 menit. Pada pertemuan ini, peneliti kembali menjelaskan materi pelajaran tentang membaca puisi dengan teknik pelatihan dasar di alam terbuka. Setiap siswa diberi kesempatan untuk membaca puisi dengan memperhatikan aspek penghatan, vokal dan performance mereka.

Setelah pembelajaran pada siklus II selesai, kemudian peneliti melakukan evaluasi post-test 2 dengan memberikan tes membaca puisi yang sudah dipelajari dari materi yang sudah peserta didik dapatkan selama proses pembelajaran siklus II. Setelah dilaksanakannya pembelajaran selama dua kali pertemuan dan satu kali pertemuan post-test 2, jumlah peserta didik yang mencapai nilai KKM mengalami peningkatan dibandingkan nilai tes pada post-test siklus I.

Adapun siswa yang mencapai nilai KKM yakni sebesar 78 adalah seluruh siswa yang berjumlah 34 orang. Sementara itu, jika dilihat dari perolehan nilai siswa dalam membaca puisi menurut pengategorian skor, siswa yang memperoleh nilai kategori sangat baik atau baik berjumlah ada 34 siswa. Hal ini dapat dilihat pada tabel berikut.

Tabel 2. Distribusi nilai post-test 1 keterampilan membaca puisi dalam skala 100

\begin{tabular}{|l|l|c|c|c|}
\hline $\begin{array}{l}\text { No } \\
.\end{array}$ & $\begin{array}{l}\text { Katego } \\
\text { ri }\end{array}$ & $\begin{array}{l}\text { Rentan } \\
\text { g Skor }\end{array}$ & $\begin{array}{l}\text { Frekuen } \\
\text { si }\end{array}$ & $\begin{array}{l}\text { Persentas } \\
\text { e }\end{array}$ \\
\hline 1. & $\begin{array}{l}\text { Sangat } \\
\text { baik }\end{array}$ & $85-100$ & 10 & $29,41 \%$ \\
\hline 2. & Baik & $70-84$ & 24 & $70,58 \%$ \\
\hline 3. & Cukup & $55-69$ & 0 & $0 \%$ \\
\hline 4. & $\begin{array}{l}\text { Kurang } \\
\text { baik }\end{array}$ & $0-54$ & 0 & $0 \%$ \\
\hline \multicolumn{2}{|l|}{ Jumlah } & & $\mathbf{3 4}$ & $\mathbf{1 0 0 \%}$ \\
\hline
\end{tabular}

Berdasarkan tabel diatas, diketahui bahwa pada post-test Siklus 2, peserta didik yang mencapai nilai dengan kategori sangat baik dengan rentang skor $85-100$ berjumlah 10 orang $(29,41 \%)$. Peserta didik yang mencapai nilai dengan kategori baik dengan rentang skor $70-84$ berjumlah 24 orang $(70,58 \%)$. Peserta didik yang mencapai nilai dengan kategori cukup dengan rentang skor 55-69 berjumlah 0 orang $(0 \%)$. Peserta didik yang mencapai nilai dengan kategori kurang baik dengan rentang skor 0-54 berjumlah 0 orang $(0 \%)$. Nilai tersebut dihitung dengan pada skala maksimal 100.

Perbandingan rentang skor hasil tes membaca puisi peserta didik pada siklus I dapat dilihat pada gambar berikut ini. 


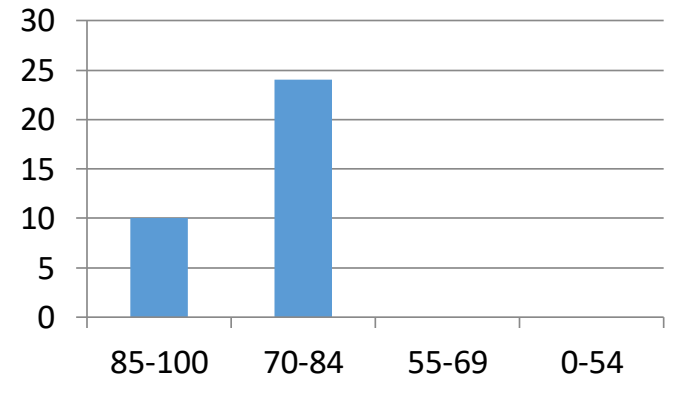

Grafik 2. Grafik persentase keterampilan membaca puisi peserta didik pada siklus II

Grafik di atas menunjukkan bahwa pada siklus II, jumlah peserta didik yang mencapai nilai KKM sebanyak 34 orang atau sebesar $100 \%$.

\section{Pembahasan Hasil Penelitian}

Evaluasi refleksi tindakan siklus II dilakukan peneliti sebagai guru Bahasa Indonesia SMA Negeri 16 Pekanbaru setelah pembelajaran dan evaluasi post-test 2 selesai dilaksanakan.

Berikut ini adalah rangkuman hasil refleksi tindakan siklus II.

a. Peserta didik mulai lancar dalam membaca puisi dengan aspek penghayatan, vokal dan penampilan dengan menggunakan bahasa Indonesia yang baik dengan dipergunakannya teknik pelatihan dasar di alam terbuka pada pembelajaran keterampilan membaca puisi.

b. Peserta didik yang sebelumnya kurang aktif di kelas, sudah mulai aktif dan berani untuk maju di depan kelas dan menulis kalimat dalam bahasa Indonesia setelah diterapkan pelatihan di alam terbuka pada pembelajaran bahasa Indonesia.

c. Peserta didik dapat mengekspresikan diri dalam membaca puisi dan meningkatnya keterampilan membaca puisi mereke berdasarkan aspek penghayatan, vokal dan penampilannya.

Selain refleksi yang dilakukan peneliti sebagai guru Bahasa Indonesia, peneliti juga melakukan wawancara refleksi tindakan siklus II dengan peserta didik. Berikut ini adalah rangkuman hasil wawancara peneliti dengan beberapa peserta didik pada refleksi tindakan siklus II. a. Penggunaan teknik pelatihan dasar di alam terbuka pada pembelajaran bahasa Indonesia dapat meningkatkan keterampilan membaca puisi peserta didik kelas XII IPS 1.

b. Peserta didik sudah dapat mengekpresikan dirinya dalam keterampilan membaca puisi

c. Peserta didik dapat mengikuti pembelajaran dengan baik dikarenakan tempat belajarnya yang sejuk dan nyaman,

d. Penggunaan teknik pelatihan dasar di alam terbuka pada pembelajaran keterampilan membaca puisi dapat membuat peserta didik meningkatkan aspek penghayatan, vokal dan penampilannya.

Selain itu dari segi peningkatan kemampuan membaca puisi, peserta didik mengalami peningkatan nilai rata-rata kelas skor hasil tes membaca puisi hingga setelah siklus ke II seluruh peserta didik mampu mencapai nilai ketuntasan KKM yaitu 78 .

Perbandingan nilai rata-rata kelas skor hasil tes membaca puisi peserta didik pada pra-siklus, siklus I dan siklus II dapat dilihat pada gambar berikut ini.

\section{Hasil Nilai Rata-rata}

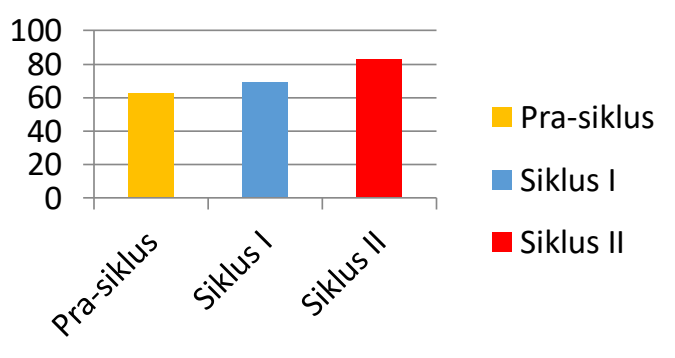

Grafik 3: Grafik perbandingan peningkatan jumlah peserta didik pada prasiklus, siklus I dan siklus II

Berdasarkan grafik di atas, tampak jelaslah bahwa skor rata-rata siswa kelas XII IPS I SMA Negeri 16 Pekanbaru dalam membaca puisi pada pra-siklus adalah 62,97. Sedangkan skor rata-rata siswa kelas XII IPS I SMA Negeri 16 Pekanbaru dalam membaca puisi pada siklus I adalah 69,32. Dan skor ratarata siswa kelas XII IPS I SMA Negeri 16 Pekanbaru dalam membaca puisi pada siklus II adalah 82,97. 
Adapun peningkatan kemampuan

siswa dalam membaca puisi setelah diterapkannya teknik pelatihan dasar di alam terbukadan setelah dilakukan tindakan kelas pada siklus I dan siklus II, yaitu:

$$
\begin{aligned}
& \mathrm{SP}=\frac{82,97-62,97}{62,97} \times 100 \% \\
& =\frac{20}{62,97} \times 100 \% \\
& =31,76 \% \\
& \text { Dengan demikian, maka diketahui }
\end{aligned}
$$
bahwa melalui penggunaan teknik pelatihan dasar di alam terbuka dapat meningkatkan keterampilan membaca puisi pada siswa kelas XII IPS 1 SMA Negeri 16 Pekanbaru setelah siklus kedua yakni sebesar $31,76 \%$.

\section{SIMPULAN}

Berdasarkan data-data, analisis, dan pembahasan dalam penelitian ini yang telah diuraikan pada bab sebelumnya, maka penulis mengambil simpulan bahwa: Pertama, terdapat peningkatan keterampilan membaca puisi siswa kelas XII IPS 1 SMA Negeri 16 Pekanbaru setelah dilakukan pembelajaran dengan menggunakan teknik pelatihan dasar di alam terbuka. Hal ini dibuktikan dari pemerolehan hasil tes siklus I yang menunjukkan nilai rata-rata yaitu sebesar 69,32 dan pada siklus II diperoleh nilai ratarata sebesar 82,97. Dengan demikian dapat diketahui bahwa terdapat peningkatan hasil dari siklus I ke siklus II sebesar 13,65 poin atau $19,69 \%$.

Kedua, terdapat perubahan perilaku siswa kelas XII IPS 1 SMA Negeri 16 Pekanbaru setelah mengikuti pembelajaran bahasa Indonesia tentang materi membaca puisi dengan teknik pelatihan dasar di alam terbuka. Dari hasil data nontes yang diperoleh selama melakukan penelitian ini, yakni berupa observasi, catatan harian dan dokumentasi, maka terdapat kesimpulan bahwa tingkah laku siswa mengalami perubahan kearah yang lebih positif. Berdasarkan data setelah menerapkan upaya pembelajaran membaca puisi dengan menggunakan teknik dasar di alam terbuka pada siklus I, diketahui bahwa terdapat perubahan tingkah laku siswa seperti lebih bersemangat dan percaya diri dalam mengikuti pembelajaran, walaupun masih terdapat tingkah negatif seperti ada beberapa siswa yang kurang fokus dan kurang percaya diri saat membaca puisi. Namun, setelah diterapkannya pembelajaran dengan teknik dasar di alam terbuka pada siklus II ini, tampak bahwa tingkah laku negatif siswa semakin berkurang dan tingkah laku positif siswa semakin bertambah. Tingkah laku positif yang semakin bertambah seperti siswa lebih fokus dalam mengikuti pembelajaran dan percaya diri saat mengekpresikan dirinya dalam membaca puisi.

\section{REFERENSI}

Arikunto, S. (2010). Penenlitian Tindakan Kelas. Jakarta: Bumi Aksara.

Asnawi, A. (2017). Pemanfaatan Blanded Learning Edmodo Grup dalam Pemebelajaran Mata Kuliah membaca. GERAM (Gerakan Aktif Menulis), 5(2), 53-61.

https://doi.org/10.1017/CBO9781107415 324.004

Doyin, M. (2008). Seni Baca Puisi. Semarang: Bandungan Institut.

Fatoni, N. dan A. N. (2016). Peningkatan Keterampilan Menulis Puisi dengan Pendekatan Joyfull Learning Melalui Media Puzzle Bermuatan Konsevasi Alam pada Siswa Kelas VII 4 SMP 1 Pengandon Kendal. Jurnal Pendidikan Bahasa Dan Sastra Indonesia, 5(1), 5663.

https://doi.org/https://doi.org/10.15294/jp bsi.v5i1.11303

Gani, E. (2014). Kiat Pembacaan Puisi: Teori dan Terapan. Bandung: Pustaka Reka Cipta.

Nuryatin, A. (2005). Pengantar Ilmu Sastra. Semarang: UNNES.

Santoso, P. (2012). Materi dan Pembelajaran Bahasa Indonesia SD. Jakarta: Universitas Terbuka.

Suharianto. (2005). Dasar-Dasar Teori Sastra. Semarang: Rumah Indonesia.

Sulkifli, \& Marwati. (2016). Kemampuan Menulis Puisi Siswa Kelas VII Smp Negeri Satu Atap 3 Langgikima Kabupaten Konawe Utara. Jurnal Bastra, 


$$
\text { 1(1), 1-22. } \quad \text { Retrieved from }
$$

http://ojs.uho.ac.id/index.php/BASTRA/a rticle/view/1058/876

Tarigan, H. G. (2008). Membaca Sebagai Suatu Keterampilan Berbahasa. Bandung: Angkasa.

Waluyo, H. J. (2005). Apresiasi Puisi untuk Pelajar dan Mahasiswa. Jakarta: Gramedia Pustaka Utama.

Zulfadli, M. (2017). Makna Idiomatik Repitisi pada Kumpulan Puisi Perempuan Wali Kota Karya Suryatati A Manan. GERAM (Gerakan Aktif Menulis), 5(1), 1-7. https://doi.org/10.1017/CBO9781107415 324.004 